\title{
Penelitian
}

\section{Histopatologi Insang Ikan Lele (Clarias bathracus) yang Terinfestasi Dactylogyrus sp.}

\author{
(Histopathological Features of the Dactylogtrus sp.-Infected Gills in the Catfish (Clarias bathracus)) \\ Putu Eka Sudaryatma*, Ni Nyoman Eriawati, Ide Fammy Panjaitan, Ni Luh Sunarsih
}

Laboratorium Uji, Balai Karantina Ikan, Pengendalian Mutu dan Keamanan Hasil Perikanan kelas I Denpasar, Bali *Penulis untuk korespondensi: putuekasudaryatma@yahoo.com

Diterima 16 April 2013, Disetujui 28 Juni 2013

\begin{abstract}
ABSTRAK
Insang ikan lele (Clarias bathracus) yang terinfestasi cacing Dactylogyrus sp. sulit untuk dapat dilihat gejala klinisnya, tetapi parasit ini sangat merugikan pada budidaya ikan lele. Perubahan histopatologi sangat konsisten terjadi pada infestasi cacing pada insang. Penelitian ini diawali dengan pemeriksaan natif insang ikan lele (Clarias bathracus) dan ikan yang terinfestasi parasit Dactylogyrus sp. dan dilanjutkan dengan pemeriksaan histopatologi. Pengumpulan sampel ikan lele (Clarias bathracus) dilakukan dari bulan Februari-September 2012 di Laboratorium Balai Karantina Ikan Pengendalian Mutu dan Keamanan Hasil Perikanan kelas I Denpasar dengan jumlah sampel sebanyak 32 kasus. Dari hasil pemeriksaan gejala klinis insang yang terinfestasi Dactylogyrus sp. didapat bahwa insang mengalami pembengkakan pada lamela insang dan berwarna merah pucat. Ukuran Dactylogyrus sp. yang ditemukan pada pengamatan preparat natif berkisar antara $200-500 \mu \mathrm{m}$. Pada pemeriksaan insang yang terinfestasi Dactylogyrus sp. terjadi perubahan histopatologi yang konsisten, yaitu hiperplasia tulang rawan hyalin, proliferasi sel mukus, hipertrofi sel klorid, hiperplasia lamela sekunder, dan fusi lamela sekunder. Perubahan ini dapat mengakibatkan kematian pada ikan akibat kekurangan oksigen dan perubahan osmoregulasi ion dalam tubuh ikan.
\end{abstract}

Kata kunci: histopatologi, insang, ikan lele (Clarias bathracus), Dactylogyrus sp.

\begin{abstract}
The clinical symptoms of catfish's gills (Clarias bathracus) that are infested by Dactylogyrus sp. are difficult to be seen. However, this parasite is highly detrimental to the cultivation of catfish. Very consistent histopathological changes occur in worm infestation of the gills. This research began with the examination of native gills of catfish (Clarias bathracus) that were infested with Dactylogyrus sp. parasite followed by a histopathologic examination. Catfish sample was collected from February to September 2012 at the Office of Fish Quarantine, Quality Control, and Fishery Safety class I in Denpasar, with a total of 32 cases. The examination of the clinical symptoms from the gills infested with Dactylogyrus sp., showed that gills were swollen on the gills' lamella and they were paler than normal. The size of the Dactylogyrus sp. that was found in the native preparation ranged from $200-500 \mu \mathrm{m}$. Histopathological changes occurred consistently, i.e. hyperplasia of hyalin cartilage, proliferation of mucous cell, hypertrophy of chloride cell, hyperplasia of secondary lamella, and fusion of secondary lamella. The changes could result in the death of the fish due to lack of oxygen and changes in the osmoregulation of ion in the fish.
\end{abstract}

Keywords: histopathology, gills, catfish (Clarias bathracus), Dactylogyrus sp.

\section{PENDAHULUAN}

Ikan lele (Clarias bathracus) merupakan komoditas perikanan air tawar yang sering dilalu-lintaskan di Balai Karantina Ikan, Pengendalian Mutu dan
Keamanan Hasil Perikanan kelas I Denpasar, terutama bibit untuk budidaya yang berasal dari daerah Jawa. Kebutuhan benih ikan lele di Propinsi Bali mencapai 12 juta ekor pada tahun 2011 (DKP Bali, 2012). 
Pemeriksaan gejala klinis parasit yang dapat terinfestasi pada insang ikan sangat sulit diamati, karena parasit hidup di eksternal tubuh ikan dan mengikuti pergerakan ikan secara bebas. Pemeriksaan dilakukan dengan observasi visual pada insang ikan yang diduga terinfeksi dan terinfestasi parasit. Pemeriksaan dilakukan dengan mengambil sampel insang dan diamati dengan mikroskop.

Parasit yang menyerang insang ikan lele (Clarias bathracus) ada banyak jenis dan tipe cara menginfeksi. Jenis parasit yang dapat menyerang pada ikan adalah golongan protozoa, cacing dan crustacea (Kabata, 1985). Penyakit parasit yang sering menyerang insang ikan lele (Clarias bathracus) dan sangat jarang menimbulkan gejala klinis secara makroskopis (Bamidele, 2007) tetapi menunjukkan perubahan histopatologi yang sangat konsisten adalah dari golongan cacing. Parasit golongan cacing terbagi menjadi Plathyhelminthes, Nematoda, dan Acanthocepala. Infestasi cacing yang sering ditemukan pada insang ikan lele (Clarias bathracus) yang berasal dari kelas Monogenea (Ordo Plathyhelminthes) adalah Dactylogyrus sp. (Hoffman, 1999), dimana perubahan histopatologi sangat jelas dan konsisten dari infestasi parasit tersebut. Dengan ditemukannya parasit pada insang, belum tentu dapat ditemukan gejala klinis yang mendukung temuan penyakit parasit tersebut.

Histopatologi merupakan suatu teknik atau ilmu yang mempelajari perubahan abnormal dari sel atau jaringan yang digunakan untuk mendiagnosa penyakit. Pemeriksaan secara histopatologi merupakan pendukung dari suatu diagnosa dan dapat menjadi pemeriksaan diagnosa utama dari suatu penyakit dengan ditemukanya perubahan sel atau jaringan yang spesifik pada penyakit tertentu. Pada saat yang bersamaan, pemeriksaan histopatologi merupakan pemeriksaan lanjutan dari penyakit parasit pada insang ikan, karena perubahan yang terjadi sering diakibatkan karena perubahan lingkungan (air pemeliharaan ikan) yang terjadi secara ekstrem (Hossain et al., 2007). Untuk itu perlu dilakukan pemeriksaan histopatologi lebih lanjut untuk mengetahui gambaran perubahan sel dan jaringan dari insang yang terinfestasi cacing Dactylogyrussp.

\section{BAHAN DAN METODE}

\section{Pengamatan Parasit Secara Preparat Natif}

Pengumpulan dan pemeriksaan sampel dilakukan selama bulan Februari-September 2012 di Labo- ratorium Parasitologi dan Histologi Balai Karantina Ikan, Pengendalian Mutu dan Keamanan Hasil Perikanan kelas I Denpasar. Ikan lele (Clarias bathracus) dianastesi dan dinekropsi, kemudian diamati gejala klinis pada insang. Insang diambil 5-6 filamen untuk diletakkan di atas gelas obyek yang sudah ditetesi $\mathrm{NaCl}$ fisiologis dan ditutup dengan gelas penutup. Preparat diamati dengan mikroskop cahaya dan direkam menggunakan kamera perekam. Setelah ditemukan parasit yang mengarah pada Dactylogyrus sp., insang dibilas dengan $\mathrm{NaCl}$ fisiologis secara perlahan dan dilanjutkan dengan proses pembuatan preparat histologis.

\section{Preparasi dan Pengamatan Preparat Histologis}

Sampel ikan yang teridentifikasi infestasi parasit pada insang di laboratorium parasitologi selanjutnya difiksasi menggunakan phospate-buffered formalin (NBF) 10\% selama 24-48 jam (Rašković et al., 2011). Setelah dilakukan fiksasi, dilanjutkan dengan tissue processing yang bertujuan untuk mempertahankan kondisi sel dan jaringan agar dapat dilakukan proses tissue embbeding. Blok-blok yang terbentuk dari proses tissue embbeding kemudian dilanjutkan dengan pemotongan jaringan menggunakan mikrotom dengan ketebalan sayatan 3-5 $\mu \mathrm{m}$. Pita hasil pemotongan diregangkan dengan cara dimasukkan ke dalam waterbath bersuhu stabil $40^{\circ} \mathrm{C}$. Gelas obyek digunakan untuk mengambil pita dalamwaterbath dan dikering-anginkan selama satu jam. Kemudian, gelas obyek disusun dalam staining box dan dilakukan pewarnaan haematoxylin-eosin (HE) dan diakhir pewarnaan dilakukan covering slide. Preparat diamati dengan mikroskop cahaya dan didokumentasikan menggunakan kamera perekam. Analisa jaringan dilakukan secara deskriptif dengan melihat perubahan jaringan yang diakibatkan oleh infestasi parasit Dactylogyrussp.

\section{HASIL}

Dari hasil pengamatan preparat natif dan histologi yang dilakukan di laboratorium, ditemukan sebanyak 32 kasus infestasi parasit Dactylogyrus sp. pada insang ikan lele (Clarias bathracus) selama bulan Februari-September 2012. Gejala klinis yang tampak adalah pembengkakan pada lamela insang dan insang berwarna lebih pucat (Gambar 1A). Ukuran Dactylogyrus sp. yang ditemukan pada pengamatan preparat natif insang berkisar antara

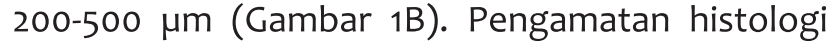
memperlihatkan adanya perubahan hiperplasia tulang rawan hyalin (Gambar 2 \& 3), proliferasi 
sel mukus, hipertropi sel klorid, hiperplasia lamela sekunder dan fusi lamela sekunder (Gambar 4 \& 5).

\section{PEMBAHASAN}

Pada Gambar 1A, ikan lele yang terinfestasi Dactylogyrus sp. memperlihatkan warna insang yang pucat dan pembengkakan pada lamella insang. Cacing Dactylogyrus sp. merupakan parasit golongan cacing yang sangat mudah dikenali pada saat pengamatan preparat natif insang ikan lele, karena ukuran parasit ini sangat besar dengan panjang parasit berkisar antara 200-500 $\mu \mathrm{m}$ (Gambar 1B). Cacing Dactylogyrus sp. merupakan parasit di kelas monogenea dengan ukuran terbesar dan memiliki panjang mencapai 0,30-1,00 mm (Kabata, 1985)

Parasit ini menempel pada permukaan lamela insang bahkan sampai menembus tulang rawan hialin. Terkadang pada pemeriksaan preparat natif, parasit hanya tampak menempel pada permukaan lamela sekunder. Parasit ini menempel pada permukaan lamela insang dengan menggunakan opistaptor yang terdiri dari 14 hooks, dua diantaranya berada di dekat anchor (Gambar 1B \& 3). Anchor merupakan alat penghisap sari makanan yang dibawa oleh darah saat mengikat oksigen di lamela insang (Kabata, 1985). Buschkiel's (1930) dalam Kabata (1985) menyebutkan bahwa telah ditemukan Dactylogyrus puntii dan Dactylogyrus cyprini di Indonesia, Malaysia, Filipina dan Thailand.

Perkembangan parasit ini sangat cepat di perairan. Telur yang menetas di perairan akan berenang menggunakan cilia yang disebut oncomirasidium untuk mencari insang definitif yang sesuai dan berkembang infektif pada ikan tersebut (Rohde, 2005). Perkembangan parasit mencapai dewasa terjadi di insang, tepatnya di lamela primer insang
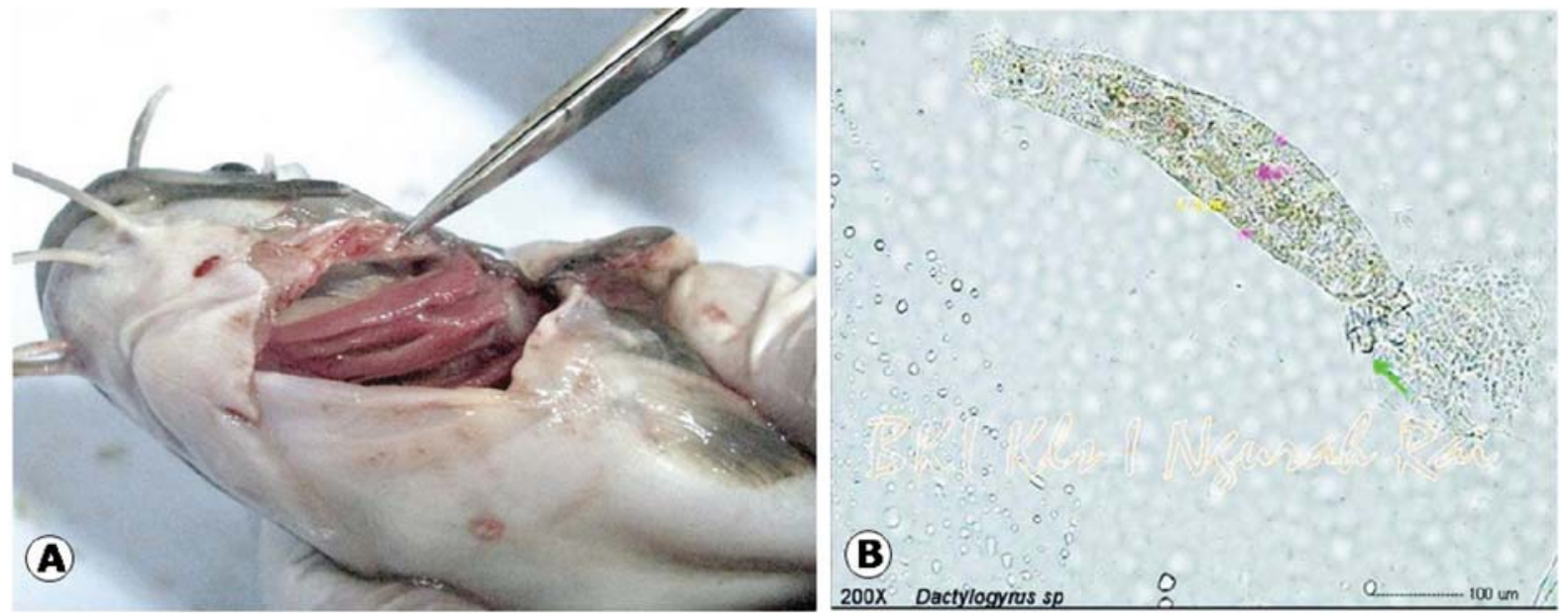

Gambar 1 Gejala klinis insang yang menebal dan berwarna lebih pucat pada ikan lele (A) yang terinfestasi Dactylogyrus sp. (B).
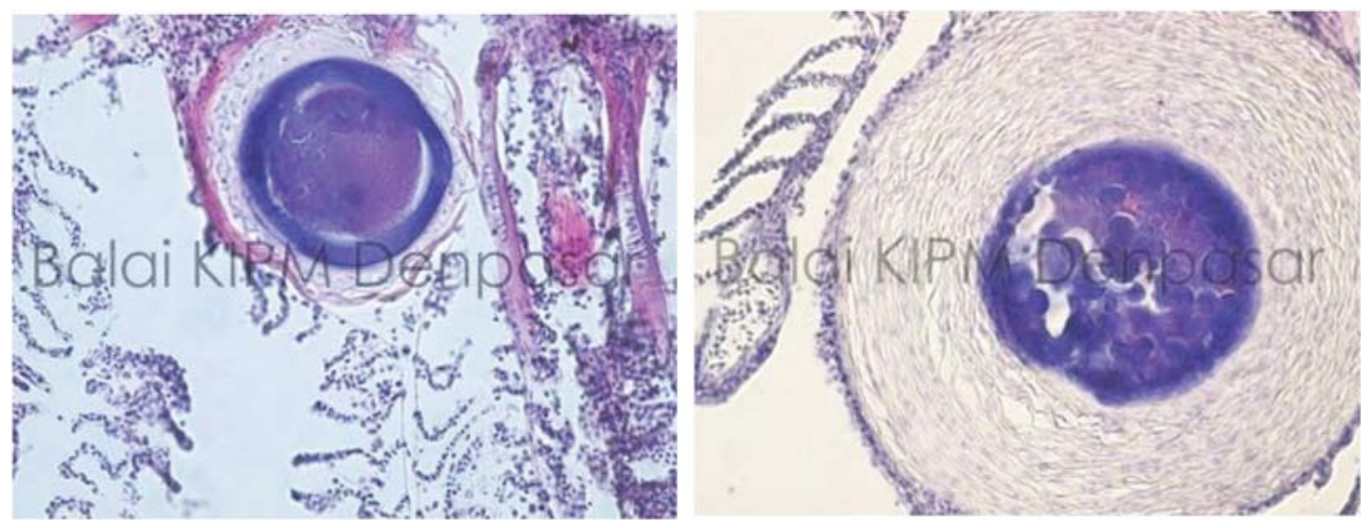

Gambar 2 Kista Dactylogyrus sp., yang ditemukan dalam lamela primer insang, menimbulkan hiperplasia tulang rawan hyalin (pewarnaan $\mathrm{HE}, 200 \mathrm{X}$ ) 


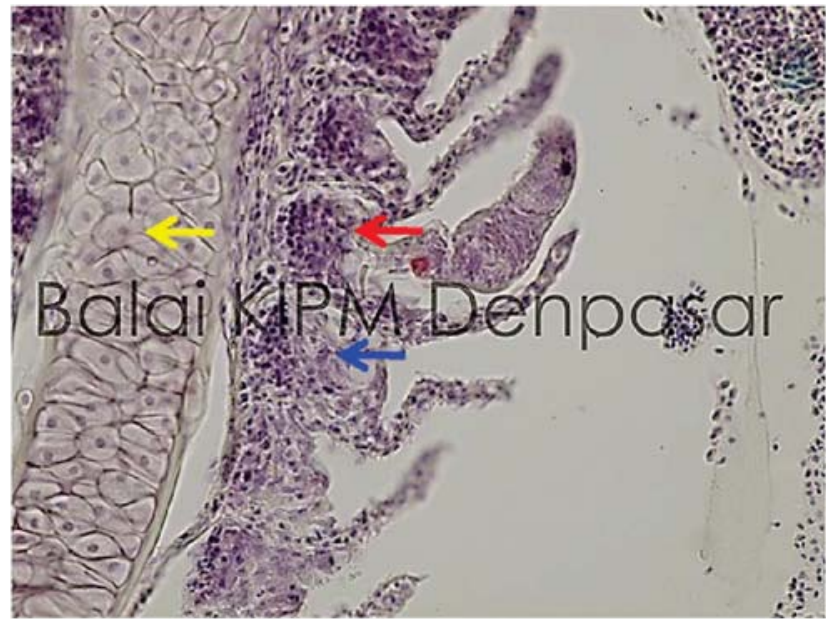

Gambar 3 Anchor Dactylogyrus sp. (panah merah) yang melekat pada lamela insang dan menyebabkan hiperplasia sel epitel lamela (panah biru) dan hyperplasia tulang rawan hyalin (panah kuning) (pewarnaan HE, 1000X)
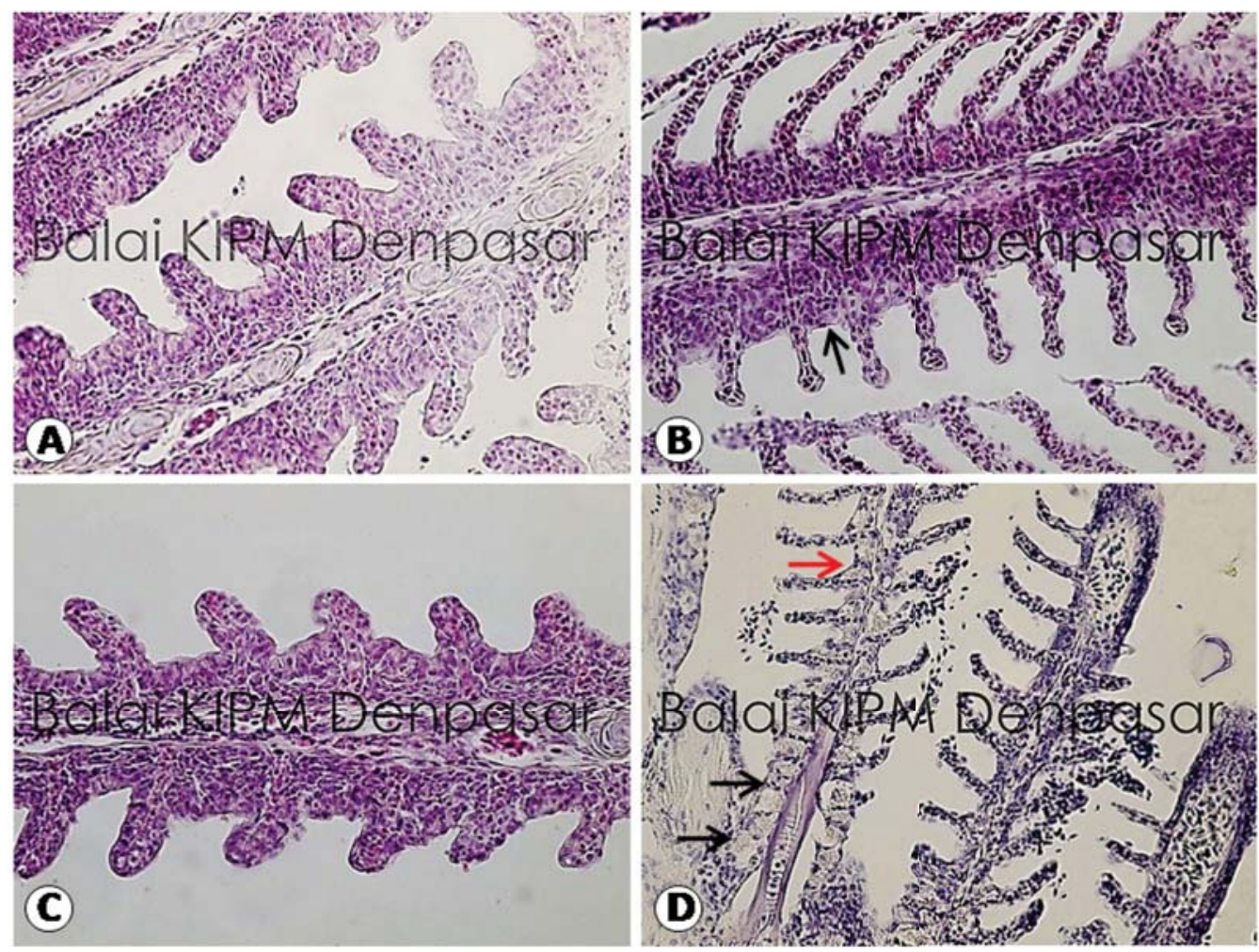

Gambar 4 Mikrofotografi insang ikan lele. A) Lakuna yang berisikan sel darah merah tertutupi oleh hiperplasia sel epitel lamela; B) Sel malpigi (panah) yang bermigrasi ke lamela sekunder; C) Hipertropi dan hiperplasia sel epitel dari lamela sekunder dari proses pertahanan insang dari parasit; D) Proliferasi sel mukus (panah hitam) dan hipertropi sel klorid (panah merah) pada lamela sekunder yang menghasilkan hipersekresi mukus dan perubahan osmoregulasi ikan (pewarnaan HE, 400X) 


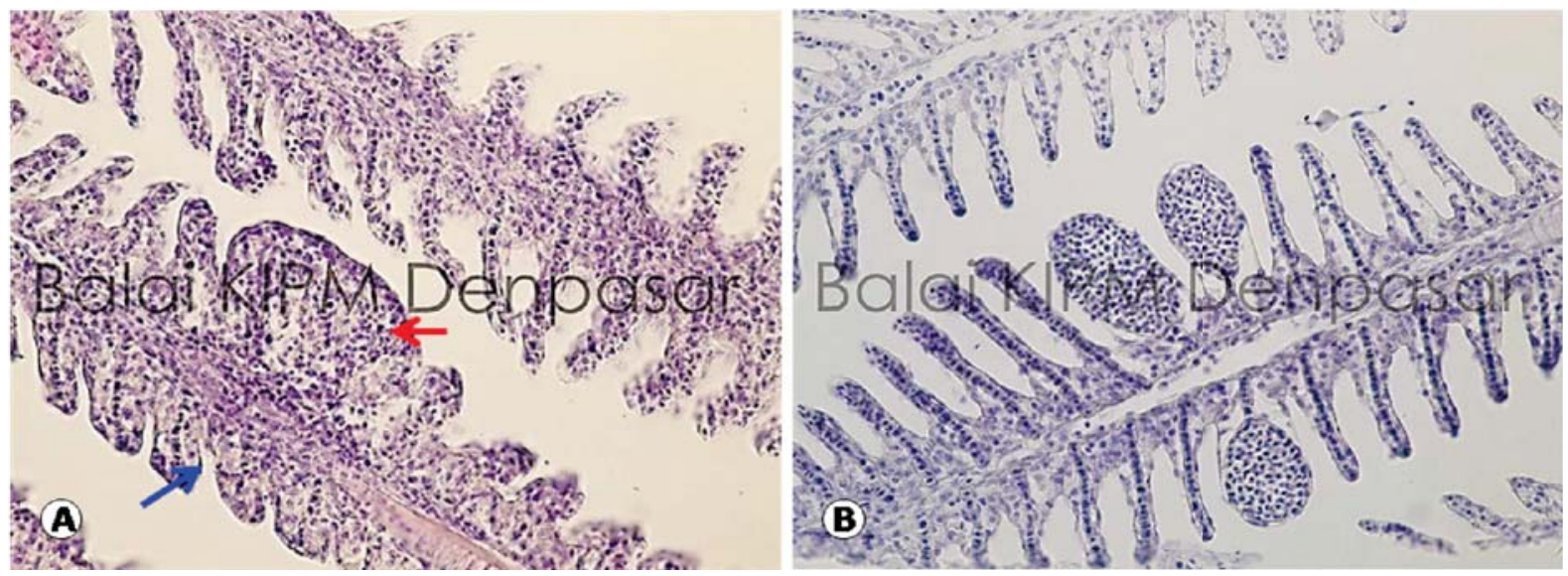

Gambar 5 Mikrofotografilamela sekunderinsang ikanlele. A)Fusilamela sekunder karena hiperplasia sel epitel lamela sekunder dan migrasi sel malpigi (panah merah); Hipertropi sel epitel lamela sekunder dan proliferasi sel mukus (panah biru). Telangiektasis yang diakibatkan karena pecahnya lakuna akibat dari ruptur sel pilar sehingga terjadi penumpukan sel darah merah di lamela sekunder (pewarnaan HE, A=400X, B=200X).

mengakibatkan perdarahan. Reaksi pertahanan pada lamela menstimulasi pertumbuhan sel epitel lamela insang yang sangat cepat (hiperplasia) dan peningkatan dari sekresi mukus oleh sel-sel mukus (Gambar 3).

Proliferasi sel mukus yang distimulasi untuk melindungi bagian tubuh yang termakan oleh parasit dengan menghasilkan banyak lendir pada permukaan insang dapat menyebabkan kematian sel (nekrosa) epitel lamela (Hossain et al., 2007). Nekrosa yang diakibatkan hipersekresi mukosa menimbulkan perforasi dari pembuluh darah, sehingga oksigen dan nutrisi tidak sampai di lokasi hiperplasia sel epitel tersebut, dalam keadaan yang lama akan menyebabkan kematian jaringan (Gambar 3 dan 4C). Peningkatan sekresi sel mukus secara nyata mengurangi proses pernafasan pada ikan karena proses osmosis oksigen tidak terjadi pada daerah yang tertutup sekresi mukus dan sel epitel yang sudah nekrosa (Roberts, 2001).

Hiperplasia lamela tidak hanya disebabkan oleh pertumbuhan sel epitel, tapi bisa juga bersinergi dengan hipertropi (pembesaran) sel epitel lamela sekunder, proliferasi dan hipertropi sel mukus, hipertropi sel klorid, dan migrasi sel malpigi di lamela sekunder. Keberadaan sel malpigi di lamela sekunder diakibatkan oleh sistem pertahanan tubuh yang mengakibatkan perkembangan sel basal lamela primer dan menyebar ke lamela sekunder (Gambar 4B).

Peningkatan jumlah sel klorid dalam insang diakibatkan oleh faktor kandungan ion yang terdapat pada air pemeliharaan, sehingga dapat menggangu proses osmoregulasi untuk menstabilkan ion di dalam tubuh ikan lele (Gambar 4D). Roberts
(2001) dan (Sudaryatma \& Eriawati, 2012) menyatakan bahwa proliferasi sel klorid dapat meningkatkan penyerapan ion aluminium dan mengganggu aliran ion $\mathrm{Na}^{+}$dan $\mathrm{Cl}^{-}$ke epitel lamela sekunder yang akan diserap langsung oleh sel darah merah sebagai proses osmosis penyerapan oksigen. Sel klorid merupakan sel utama dalam osmoregulasi pada ikan dan sangat jelas tampak pada pewarnaan secara histologis (Chinabut et al., 1991).

Tingkat infestasi yang parah dapat mengakibatkan kematian pada ikan. Hal ini diakibatkan karena fusi (perlekatan) dari lamela sekunder (Gambar 5A). Fusi dari lamela sekunder mengakibatkan tugas lamela tidak dapat berfungsi dengan baik, karena lakuna yang berisi sel darah merah tertutup oleh sel epitel lamela sekunder dan sel malpigi yang bermigrasi. Fusi lamela berisikan surfaktan dari sel mukus, sel malpigi dan terjadi penebalan inti yang berbentuk bulan sabit yang dapat terdistribusi sampai ke lamela primer (Roberts, 2001).

Tertutupnya lakuna oleh sel epitel lamela sekunder dapat meningkatkan tekanan yang ada di lakuna dan mengakibatkan ruptur (patah) dari sel pilar yang berfungsi menjaga kestabilan dari lamela sekunder. Patahnya sel pilar mengakibatkan penumpukan sel darah merah di ujung lamela yang disebut dengan telangiektasis (Gambar 5B).

Telangiektasis dapat diakibatkan oleh proses normal tubuh dimana penyerapan oksigen rendah sedangkan kebutuhan oksigen untuk metabolisme sangat tinggi sehingga ikan melakukan homeostasis dengan mempercepat peredaran darah yang mengakibatkan patahnya sel pilar dan memperluas area lakuna di ujung lamela sekunder (Roberts, 2001; Sayed et al., 2012). 
Dari hasil pemeriksaan ini maka dapat disimpulkan bahwa insang ikan lele yang terinfestasi Dactylogyrus sp. memiliki gejala klinis insang berwarna merah pucat dan mengalami pembengkakan pada lamela. Ukuran Dactylogyrus sp. yang ditemukan pada pengamatan preparat natif insang berkisar antara 200-500 $\mu \mathrm{m}$. Pengamatan histopatologi insang menggambarkan adanya konsistensi perubahan yaitu hiperplasia tulang rawan hyalin, proliferasi sel mukus, hipertropi sel klorid, hiperplasia lamela sekunder dan fusi lamela sekunder. Fusi lamela sekunder dapat mengakibatkan terjadinya telangiektasis dan mengakibatkan kematian ikan karena kekurangan oksigen dan perubahan osmoregulasi ion tubuh ikan.

"Penulis menyatakan tidak ada konflik kepentingan dengan pihak-pihak yang terkait dalam penelitian ini".

\section{DAFTAR PUSTAKA}

Bamidele A. 2007. Histopathological study on the parasitised visceral organs of some fishes of Lekki Lagon, Lagos, Nigeria. Life Science Journal 4(3): 70-76.

Camargo MMP, Martinez CBR. 2007. Histopathology of gills, kidney and liver of a neotropical fish caged in an urban stream. Neotropical Ichthyology 5(3): 327-336.

Chinabut S, Limsuwan C, Kitsawat P. 1991. Histology of the Walking Catfish, Clarias bathracus. International Development Research Centre. Canada. p28-31.
[DKP Bali] Humas Dinas Kelautan dan Perikanan Propinsi Bali. 2012. Laporan Data Pemasukan dan Kebutuhan Benih Ikan untuk Propinsi Bali 2011. Dinas Kelautan dan Perikanan Propinsi Bali. Denpasar.

Grabda J. 1991. Marine Fish Parasitology. PWN Publishers. Poland. p85-98.

Hoffman GL. 1999. Parasites of American Freshwater Fishes. $2^{\text {nd }}$ ed. Cornell University Press. New York. p122-129.

Hossain MK, Hossain MD, Rahma MH. 2007. Histopathology of some diseased fishes. Journal Life Earth Science 2(2): 47-50.

Kabata Z. 1985. Parasites and Diseases of Fish Cultured in the Tropics. Taylor \& Francis Ltd. Great Britain. p189-194.

Rašković BS, Stanković MB, Marković ZZ, Poleksić VD. 2011. Histological methods in the assessment of different feed effects on liver and intestine of fish. Journal of Agricultural Sciences 56(1): 87-100.

Roberts RJ. 2001. Fish Pathology. $3^{\text {rd }}$ ed. WB. Saunders. China. p65-94.

Rohde K. 2005. Marine Parasitology. CSIRO Publishing. Australia. p189-196.

Sayed AH, Mekkawy IA, Mahmoud UM. 2012. Histopathological alterations in some body organs of adult Clarias gariepinus (Burchell, 1822) exposed to 4-nonylphenol. In: García MD (ed). Zoology. InTech. Shanghai. p163-184.

Sudaryatma PE, Eriawati NN. 2012. Histopatologis insang ikan hias air laut yang terinfeksi Dactylogyrussp. Jurnal Sains Veteriner 30(1): 68-75. 